\title{
GENERAL SALES AND USE TAXES AND THE COMMERCE CLAUSE
}

The power of states, under the Commerce Clause, to impose general sales and use taxes on interstate transactions has been the topic of much discussion. ${ }^{1}$ The general problem may be stated as follows. Many states have enacted general retail sales taxes. The bulk of these states have also enacted general use taxes. The object of the use tax is to complement the sales tax by taxing the use of property purchased at retail which has for some reason escaped the local sales tax, in an attempt to place all persons selling to local purchasers in the same competitive position. In the case of an interstate sale, if all states in which part of the transaction takes place impose sales or use taxes on the transaction, such sales would be more heavily taxed than purely local transactions. On the other hand, if no state could tax an interstate transaction, local commerce would be put at a disadvantage. The Supreme Court has rejected both of these extremes. It is having a difficult time working out a compromise.

On May 15, 1944, the Supreme Court decided three cases ${ }^{2}$ dealing with this problem.

McLeod v. Dilworth $\mathrm{Co}^{3}$ involved the Arkansas retail sales tax. The taxpayers were Tennessee corporations not qualified to do business in Arkansas and having no place of business there. Orders were solicited in Arkansas by traveling salesmen, or by mail or telephone. After acceptance of the orders in Tennessee, shipments were made from Tennessee direct to purchasers in Arkansas where possession was transferred from the carrier to the purchaser. Title passed in Tennessee on delivery to the carrier. In a five to four decision ${ }^{4}$ the Court held that the tax as applied to these transactions would contravene the Commerce Clause. The theory of the majority opinion, by Mr. Justice Frankfurter, was that interstate sales could be taxed only

1 Some of the discussions are Lockhart, The Sales Tax in Interstate Commerce (1939) 52 Harv. L. REv. 617; Traynor, State Taxation and the Commerce Clause in the Supreme Court, 1938 Term (1940) 28 CaLIf. L. Rev. 168; Powell, New Light on Gross Receipts Taxes (1940) 53 HaRv. L. Rev. 909; McNamara, Jurisdictional and Interstate Commerce Problems in the Imposition of Excises on Sales (1941) 8 LAW AND Contenrp. Prob. 482; Brown, The Future of Use Taxes (1941) Ibid. at 495; Morrison, State Taxation of Interstate Commerce (1942) 36 ILL. L. Rev. 727 ; Lockhart, Gross Receipts Taxes on Transportation and Communication (1943) 57 HaRv. L. Rev. 40.

2 International Harvester Co. v. Dept. of Treasury (1944) .... U.S. ...., 88 L.ed. Adv. Ops. 905, 64 S. Ct. 1019; McLeod v. Dilworth Co. (1944) .... U.S. ...., 88 L. ed. Adv. Ops. 910, 64 S. Ct. 1023, and General Trading Co. v. State Tax Commission (1944) .... U. S. ..., 88 L. ed. Adv. Ops. 914, 64 S. Ct. 1028.

3 Ibid.

4 Mr. Justice Douglas, with whom Mr. Justice Black and Mr. Justice Murphy concurred, wrote a dissenting opinion. Mr. Justice Rutledge wrote a separate dissenting opinion. 
by the state where the sale occurs. Since the sales occurred in Tennessee, Arkansas had no power to apply a sales tax to the transactions. Inasmuch as Tennessee has no general retail sales tax and Arkansas has no use tax, the sales in this case escaped taxation altogether, and were thus given a competitive advantage over local sales in Arkansas.

On the other hand, in General Trading Co. v. State Tax Comm.," where the facts were substantially identical with those in the Dilworth case, it was held that Iowa, the state of market, could constitutionally impose a tax on the use of the property after its receipt by the lowa buyer, and require it to be collected by the out-of-state seller, a Minnesota corporation.

In the third case, International Harvester Co. v. Dept. of Treasury, ${ }^{6}$ the Indiana gross mcome tax was at issue. The seller, a foreign corporation authorized to do business in Indiana, maintained manufacturing and sales branches in that state and in other states. In a seven to one decision, ${ }^{7}$ the Court held that the tax could be applied to three particular classes of interstate sales. In Class $C$ sales Indiana buyers bought from branches of the seller outside Indiana. The contracts of sale were entered into outside Indiana. Buyers took delivery to themselves at factories of the seller in Indiana. In Class $D$ sales buyers outside Indiana bought from branches in Indiana. The contracts were entered into in Indiana. The buyers came into Indiana to take delivery to themselves at factories of the seller. In Class $E$ sales Indiana buyers made purchases from Indiana branches and the contracts were made in Indiana, but the goods were shipped by the seller from factories outside the state to the buyers in Indiana. Mr. Justice Douglas, speaking for the majority, gave the following reasons for sustaining the tax on these sales. In all three classes of sales there are local transactions, distinct from the interstate phases, which are adequate taxable events: in Class $C$ sales, the delivery of the goods in Indiana; in Class $D$ sales, the delivery of the goods and the making of the contracts in Indiana; in Class $E$ sales, the consummation of the transactions in Indiana. In none of the classes of sales is there any discrimination against interstate commerce.

The reader of the majority and minority opinions in these cases is confronted with inconsistencies and a conflict in the views of the various nembers of the court. These may best be understood by a brief review of the earlier cases.

5 Suprà note 2.

6 Ibid.

7 Mr. Justice Jackson dissented without opinion. Mr. Justice Roberts did not participate.

8 See references supra note 1 , for discussions of this line of cases . 
In Western Live Stock v. Bureau of Int. Rev. ${ }^{9}$ decided in 1938, the Court introduced the doctrines that interstate commerce should bear its fair share of the local tax burdens; and that gross receipts from interstate transactions could be taxed if the tax was not of a type which could be repeated by other states, subjecting interstate commerce to the risk of multiple tax burdens. Accordingly the Court sustained a tax by New Mexico on the gross receipts of a publisher from the sale of advertising, although the circulation was partly interstate, and some of the contracts were with out-of-state advertisers.

In Adams Mfg. Co. v. Storen ${ }^{10}$ the Indiana gross income tax was condemned as applied to the gross receipts from sales by an Indiana corporation with factory and home office in the state to dealers in other states. Orders were accepted at the home office and shipments were made from the factory in Indiana. It is not clear where title passed. ${ }^{11}$ The reasons given in support of the decision were (1) that the tax was applied, without apportionment, to receipts from imterstate activities; and (2) that similar taxes could, in substance, be levied by the states in which the goods were sold, or in other states, subjecting interstate commerce to the risk of a multiple tax burden.

The same principles were followed in Gwin, White \& Prince $v$. Henneford ${ }^{12}$ where the Court held that the Commerce Clause precluded the state of Washington from applying its business activities tax to the gross receipts from sales by a marketing agent, a Washington corporation with a place of business in that state, to out-ofstate buyers. The contracts were made outside the state, and the fruit was shipped to the buyers after having been shipped, consigned to the seller, to points outside the state.

Mr. Justice Black wrote dissenting opinions in these two cases. He objected to condemning the taxes merely because of the risk of multiple tax burdens. His view was that non-discriminatory taxes on transactions with interstate attributes should not be declared unconstitutional unless more than one tax had actually been imposed on the same transaction. In the absence of actual multiple burdens, if the non-discriminatory taxes of many states raise a problem, only Congress should have the power to consider it.

In McGoldrick v. Berwind-White Coal Mining Co. ${ }^{13}$ the New York City sales tax was sustained where a Pennsylvania corporation

9 (1938) 303 U.S. 250,115 A. L. R. 944.

10 (1938) 304 U.S. 307,117 A.I. R. 429.

11 In the Berwind-White case, infra, note 13, Mr. Justice Stone apparently assumed that title passed outside the state in the Adams Mfg. Co. case, since he described the transaction as "sales of goods manufactured in the taxing state and sold in other states...," 309 U. S. at 57.

12 (1939) 305 U.S. 434.

13 (1940) 309 U.S. 33, 128 A.I. R. 876. 
with a sales office in New York entered into contracts in New York with New York purchasers for the sale of coal produced in Pennsylvania. The coal was shipped by the seller to New York, and delivered in New York. Mr. Justice Stone, speaking for the majority, reasoned somewhat as follows. Interstate commerce must bear its fair share of the state tax burdens, but the Commerce Clause prohibits state taxes which aim at or discriminate against interstate commerce. The tax here is non-discriminatory because it is based on a local taxable event, delivery of goods within the state upon their purchase for consumption. A sales tax by the state of market has no different effect upon interstate commerce than a use tax imposed after an interstate movement of goods, and the latter had previously been declared constitutional. ${ }^{14}$

On the authority of the Berwind-White case the New York City sales tax was upheld in three companion cases. In McGoldrick v. Compagnie Generale Transatlantique ${ }^{15}$ and Jagels, "A Fuel Corporation" v. Taylor ${ }^{16}$ the facts were essentially the same as those in the Berwind-White case, with the exception that in the Jagels case the contracts were made outside the city. In McGoldrick v. Felt \& Tarrant Mfg. Co., ${ }^{17}$ also decided concurrently with the Berwind-White case, there were material differences. The respondent $\mathrm{Du}$ Grenier, Inc. had no place of business in New York, accepted sales orders in Massachusetts, and shipped the goods to New York purchasers, f.o.b. points in Massachusetts; in short, the facts were the same as those in the Dilworth case. Without discussing the differences, the Court in the Felt \& Tarrant case said that, like in the Berreind-White case, the "transfer of possession" took place in New York. ${ }^{18}$ Apparently the Court meant that transfer of the goods from the carrier to the buyer within the state was a "transfer of possession" sufficient to support the tax.

The next two cases were concerned with the Indiana gross income tax. In Dept. of Treasury v. Wood Preserving Corp..$^{10}$ the seller, a Delaware corporation with a creosoting plant in Ohio, entered into a contract outside Indiana with a railroad company for the sale of ties to be delivered f.o.b. points in Indiana and shipped by the railroad to the seller's plant in Ohio for creosoting. In a unanimous decision the Court sustained the tax on the gross receipts from these sales. The decision was placed on the ground that the tax was levied

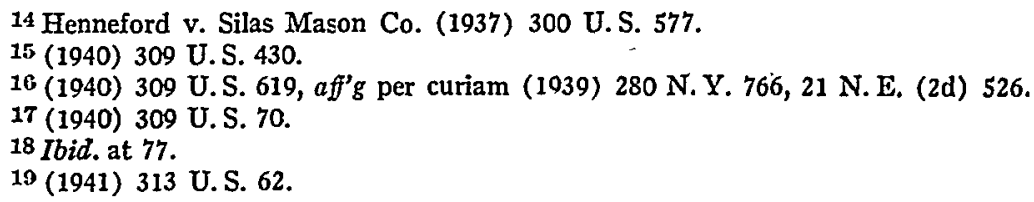


upon receipts from local intrastate transactions (sales and deliveries within the state), despite the fact that the ties were immediately shipped out of the state by the buyer pursuant to the contract.

In Allied Mills v. Dept. of Treasury ${ }^{20}$ the tax was also upheld as applied to the receipts from sales by an Indiana corporation with plants in Indiana and Illinois to Indiana customers, where the orders were accepted in Illinois and the goods were shipped from Illinois plants direct to the Indiana customers to save freight. The opinions did not state where title passed. The Indiana Supreme Court sustained the tax because it thought that the trend in the decisions of the United States Supreme Court was in the direction of supporting sales taxes by the buyer's state. The latter Court affirmed the decision per curiam.

It should be noted that the Supreme Court has never had before it a case where more than one state had actually imposed sales or use taxes on the same transaction.

This brings us to the three cases under discussion.

The International Harvester case is in line with previous cases. As in the Berwind-White and companion cases, ${ }^{21}$ Dept. of Treas. $v$. Wood Preserving Corp., ${ }^{22}$ and Allied Mills v. Dept. of Treasury, ${ }^{23}$ the tax was sustained where the buyer physically received the goods within the taxing state. The principles followed in the International Harvester case were similar to those laid down in the Bervind-White case.

The General Trading Co. case is also in line with earlier cases. The Court had previously held that a use tax may be imposed on property which has been brought into the state by the taxpayer after purchase at retail in another state. ${ }^{24}$ And this was held to be so whether or not the use tax statute makes provision for a credit for sales or use taxes paid to other states. ${ }^{25}$ Furthermore, a use tax may be levied where the property is purchased in another state and brought into the taxing state for use in interstate commerce, such as equipment and supplies for a railroad, ${ }^{26}$ or a telephone and telegraph conspany. ${ }^{27}$ As for collection, the Court had held that an out-of-state seller could be required to collect the tax from the buyer for the state where the seller had only a sales office ${ }^{28}$ or retail stores in the state. ${ }^{20}$

\footnotetext{
20 (1943) 318 U. S. 740, aff'g per curiam (1942) 220 Ind. 340, 42 N. E. (2d) 34.

21 Supra notes $13,15,16$, and 17 .

22 Supra note 19.

23 Supra note 20.

24 Henneford v. Silas Mason Co., supra note 14.

25 Southern Pacific v. Gallagher (1939) 306 U.S. 167.

28 Ibid.

27 Pacific Telephone and Telegraph Co. v. Gallagher (1939) 306 U.S. 182.

28 Felt \& Tarrant Mfg. Co. v. Gallagher (1939) 306 U.S. 62.
} 
The General Trading Co. case goes one step further in holding that the power of the state to require collection by an out-of-state seller extends to the case of a foreign corporation not qualified to do business in the state and with no offices or branches in the state.

The Dilworth case, however, creates difficulties. In order to explain why Arkansas, the state of market, could not levy a sales tax in the Dilworth case, while (on the authority of the General Trading Co. case) it could have levied a use tax, Mr. Justice Frankfurter had to draw a distinction between a sales tax and a use tax. He called the two taxes different in substance; the former being a tax on the purchase or sales transaction and the latter on the use transaction. The majority opinion in the International Harvester case, on the other hand, called the two the same in substance, and the same in their effect on interstate commerce. Surprisingly enough Mr. Chief Justice Stone, Mr. Justice Frankfurter, and Mr. Justice Reed were part of the majority in both cases, but made no explanation of this inconsistency in the opinions.

The Dilworth case is squarely contra to McGoldrick v. Felt \& Tarrant Mfg. $\mathrm{Co}^{30}$ In both cases orders were solicited in the taxing state (or city) by a sales agent, forwarded to the out-of-state seller for approval, and the goods were shipped f.o.b. points outside the state direct to the purchasers in the taxing state. The sales tax was sustained in the Felt \& Tarrant case, but condemned in the Dilworth case. Nevertheless the Felt $\&$ Tarrant case, although involving precisely the same essential facts, was not expressly overruled in the majority opinion in the Dilworth case. Notwithstanding its patent inconsistency with the Dilworth holding, however, the majority in the International Harvester case, including the three of the five who constituted the majority in the Dilworth case, cited the Felt \& Tarrant case with approval, reasoning that since the tax there was upheld, the tax on Class $E$ sales must be equally valid. We are thus presented with the anomaly of a case being overruled and followed on the same day. It is hardly necessary to say that the net result is one of almost unparalleled confusion.

Nor is the confusion appreciably lessened by looking solely to the facts of the decided cases and ignoring the reasoning. In the fact situation in the Dilworth case, for exarnple, the state of the buyer cannot impose a sales tax because of the Dilworth holding, and neither, apparently, can the state of the seller, because a tax by the state of the seller in such a fact situation was condemned in Adams

29 Nelson v. Sears, Roebuck \& Co. (1941) 312 U.S. 359, 132 A. L. R. 476; Nelson v. Montgomery Ward \& Co. (1941) 312 U. S. 373.

30 Supra note 17. 
Mfg. Co. v. Storen. ${ }^{31}$ If we look only at the holdings, then, in this very common situation, we would be compelled to conclude that no state may levy a sales tax on any part of the transaction.

The Dilworth case makes it difficult to tell just what the attitude of a majority of the Court is today. Mr. Justice Douglas, with whom Mr. Justice Black and Mr. Justice Murphy concurred, wrote a dissenting opinion in the Dilworth case. After pointing out that the case was contra to McGoldrick v. Felt \& Tarrant Mfg. Co. ${ }^{32}$ and objecting to the distinction drawn between a use and a sales tax, Mr. Justice Douglas called the Dilworth case a retreat from the philosophy of the Berwind-White case. That philosophy, according to Mr. Justice Douglas, is that interstate commerce should bear its fair share of the tax burdens in the localities where it finds its markets. His view is that the mere receipt of goods by the buyer in the state of market is a local transaction, or taxable event, furnishing a sufficient basis for a non-discriminatory sales or use tax by the state of market. The majority opmion in the International Harvester case, also by $\mathrm{Mr}$. Justice Douglas, was written in these same terms.

Mr. Justice Rutledge wrote a separate opinion concurring with the International Harvester and General Trading Co. cases and dissenting from the Dilworth decision. Briefly, his view is that to avoid unduly burdening interstate commerce, where more than one state seeks to impose a sales or use tax on an interstate transaction, all except one must fall, or be required to give way by allowing a credit, or there must be an apportionment. Of these alternatives he favors requiring all except one to fall or to allow credit. If a choice between the state of origin and the state of market be necessary, the state of market should be given the exclusive power to tax, as that is where the goods come into competition with those sold locally.

The attitude of the majority in the Dilworth case is not clear. Since Mr. Justice Stone, Mr. Justice Frankfurter and Mr. Justice Reed were part of the majority in both the Dilworth and the International Harvester cases, it must be assumed that they favor the state of market, with the limitation that where a state purports to tax a sale as did Arkansas in the Dilworth case, the sale must take place within the state, using "both business and legal notions" 33 to determine where it takes place. One objection to the limitation is that the test to determine where the sale takes place is vague. If the majority opinion in the Dilworth case is an indication, the method apparently involves a balancing of the various attributes of the trans-

31 Supra note 10.

32 Supra note 17.

33 McLeod v. Dilworth Co., supra note 2, 64 S. Ct. at 1025. 
action which takes place in each state, such as passage of title, delivery, making of contract, and payment, and the places of business of the seller. Another objection to the limitation is that it is difficult to tell what the court will decide when the state of origin imposes a sales tax on an interstate sale occurring within its borders, and the state of market imposes a tax on the use of the property. The logical inference to be drawn from the statement in the majority opinion in the Dilworth case that the sales and the use taxes are taxes upon different transactions is that both should stand. But if both were allowed to stand, the result, in effect, would be an actual discrimination against the out-of-state seller.

The confusion arising from these cases indicates the desirability of the adoption by the Court of a simple, effective policy. It would not seem to be wise to grant interstate sales complete immunity from taxation, as local commerce would be placed at a competitive disadvantage. Apportionment of a tax between states would present cumbersome administrative problems. The Court, it is submitted, should give the state of market the exclusive power to tax (because that is where out-of-state goods come into competition with local goods); or adopt the view of Mr. Justice Black ${ }^{34}$ that any state having any connection with the interstate transaction, however remote, should be allowed to impose a non-discriminatory tax, and if such taxes by many states create problems, Congress should correct the situation by appropriate legislation.

James L.Wood.

${ }^{34}$ See his dissenting opinions in Adams Mfg. Co. v. Storen, supra note 10, 304 U.S. at 316 et seq. and Gwin, White \& Prince v. Henneford, supra note 12, 305 U.S. at 442 et seq. 